\title{
A REZILIENCIA ÉRTELMEZÉSÉNEK LEHETŐSÉGEI: KIHÍVÁSOK ÉS NEHÉZSÉGEK
}

\author{
SZABÓ DÓRA FANNI
}

\author{
SZTE BTK Neveléstudományi Doktori Iskola \\ E-mail: szabodorafanni@edu.u-szeged.hu
}

Beérkezett: 2016. február 18. - Elfogadva: 2016. szeptember 4.

\begin{abstract}
Mind gyakrabban alkalmazott terminus a reziliencia (rugalmasság), amely rendszerfogalom mivolta következtében gyorsan terjed a tudományágak között új kutatási területeket és célokat létrehozva. A fogalmat a társadalomtudományok terén a rizikós körülményekkel, nehézségekkel sikeresen megküzdố gyermekek és felnôttek esetében alkalmazzák. A jelenség két alapkritériumának, a rizikónak és a kedvezô fejlódési kimenetelnek a vizsgálata, valamint a hátterében álló okok azonosítása intenzíven kutatott területté vált. A nemzetközi kutatások eredményeinek megismerése, a nézôpont, valamint a módszerek felhasználása és hazai vizsgálatok kivitelezése szükségszerú. Azonban a témával foglalkozó jelentôs hazai tanulmányok száma igen csekély (Békés, 2002; Ribiczey, 2008; Szokoszky és V. Komlósi, 2015).

A jelenség komplexitása és jelentéstartalmának tisztázatlansága következtében számos tényezốt figyelembe kell venni a kutatások megbizhatóvá tételéhez. A tanulmány célja ezeknek a tényezóknek a számbavétele annak érdekében, hogy hozzájáruljon a hazai kutatások megtervezéséhez és kivitelezéséhez.

A kutatások felépitését és a kapott eredmények általánosithatóságát nagyban meghatározza a reziliencia definíciója, ezért a tanulmány a fogalom meghatározásának sokféleségébôl indul ki. Ezt követöen a jelenség két alapkritériumának az értelmezésében és értékelésében szerepet játszó körülményeket járja körbe, valamint kitér az értékelésükhöz felhasználható módszerek összegzésére. Végül bemutatja a kedvezô fejlōdési kimenetel létrejöttéhez feltétlen szü̈kséges erôsségek, eröforrások és protektív tényezôk koncepciójának alapfogalmait, valamint a reziliencia változókra és személyekre fókuszáló modelljeit.
\end{abstract}

Kulcsszavak: reziliencia, értékelés, rizikótényezók, protektív tényezók 


\section{BEVEZETÉS}

A társadalomtudományok terén kezdetben a pszichológiában jelentek meg a '60-as és '70-es években a rizikófókuszú longitudinális kutatások. A kutatók rámutattak, hogy az ugyanolyan vagy hasonlóan rizikós feltételek között felnövôk csoportján belül is óriási a fejlôdési kimenetelben való heterogenitás (Rutter, 2007). A gyermekek egy része meglepốn jól teljesít a többiekhez képest a hasonlóan kedvezôtlen feltételek ellenére (Masten és Powell, 2003). Egyes gyermekek esetében súlyos, az egész életvitelre kiható problémákhoz vezet a rizikónak való kitettség, míg mások hozzávetôlegesen jól alkalmazkodnak és sikereket érnek el.

A kutatási eredmények és a háttérben meghúzódó szemléleti váltások hatására megkezdôdött a pozitív adaptációt középpontba állító, reziliencia szempontú kutatásokra való hangsúlyáttevôdés. A kutatási terület kialakulásának körülményeirôl, a hátterében meghúzódó szemléletváltásról és az ökologizálódó tudományokról bôvebben olvashatunk Békés (2002) és Ribiczey (2008) tanulmányában. Egy, a reziliencia témakörét komplexebben bemutatni kívánó különszámban pedig Szokolszky és V. Komlósi (2015) részletesen bemutatja a paradigma kialakulásához vezetô folyamatokat.

\section{A REZILIENCIA KOMPLEXITÁSA}

Fiatalsága ellenére egy igen komplex területtel állunk szemben. A kutatási eredmények egységesítését számos probléma nehezíti meg, valamint számos szempontot kell figyelembe venni a kutatások megtervezésekor. Az összetettséghez nagyban hozzájárul a fogalom operacionalizálásában való inkonzisztencia (Lerner, 2006). Az elmúlt ötven évben a reziliencia számos értelmezése terjedt el, a közmegegyezésen alapuló definíció kialakítása még várat magára. A kutatások ezért az éppen alkalmazott fogalomnak megfelelô koncepciókat és értékelési formákat alakítottak ki.

\section{A reziliencia fogalmának alakulása}

A kialakult rezilienciafogalmak eltérnek annak megállapításában, hogy miként írható le maga a jelenség (Kaplan, 2005), hogy a személyen belül lokalizálható jellemvonásként, folyamatként vagy valaminek a végeredményeként, kimeneteleként értelmezhetô. Eleinte a szélsôségesen rossz helyzetben levôk körében megmutatkozó paradox öngyógyító képességként tekintettek rá. A korai kutatásokban azt feltételezték, hogy a reziliencia a személyen belül lokalizálható (Block és Block, 1980) mint személyiségbeli jellemvonás. A viszontagságokhoz, stresszhez való sikeres alkalmazkodást egyfajta képességként, a gyermek kompetenciájának megnyilvánulásaként értelmezték, amelyet az egyén veleszületett komponensei befolyásolnak, és a külsố negatív hatások révén aktivizálódik (Garmezy, Masten és Tellegen, 1984). Ezek az értelmezések kezdetben jól beillettek az egyén fejlôdésével foglalkozó elméletekbe, azonban késôbb súlyos problémát jelentett az intrapszichésen értelmezhetô reziliensreakció kiszámíthatat- 
lansága, és a statikus értelmezéseket felváltották az összetettebb, ökológiai szemléletú definíciók (Békés, 2002). Az új szemlélet a személyiség rezilienciáját viszonyfogalomként értelmezte, amelyben már nemcsak az egyénból fakad a reziliens viselkedés, hanem az öröklött biológiai és pszichológiai adottságok, valamint a környezeti faktorok (pl. családi környezet, támogatás mértéke) együttes hatása váltja ki az adaptív reakciót (pl. Masten, 2001).

A jelenség kialakulásra ható tényezók körének bôvülése mellett az új szemléletmód a reziliencia alapértelmezésére is kihatott. Egyes kutatók nem jellemvonásként, hanem folyamatként kezdték értelmezni azt. Sugland, Zaslow és Nord (1993) a nehézségekkel való megküzdés dinamikus mivoltára, folyamatjellegére hívja fel a figyelmet. Sroufe (1997) szintén folyamatként értelmezi és elkülöníti a biológiai, a pszichológiai és a szociális faktorok szerepét. Luthar, Cicchetti és Becker (2000) értelmezésében a reziliencia egy kétdimenziós dinamikus folyamat, amelyben külön dimenzióként jelenik meg a jelentôs hátrányokkal való megküzdés és a pozitív eredmények elérése.

Más kutatók a végeredménnyel, kimenetellel kapcsolatban kezdték értelmezni a jelenséget. Kaplan (1999) megállapítása szerint azonban ezen a területen is igen változatosak a megfogalmazások, és a definíciók különbségeit több forrásra is visszavezette. Bizonyos szerzók szerint a reziliencia terminus azonos a végeredménnyel, az akadályok ellenére való túléléssel. Például Masten, Best és Garmezy (1990) alapértelmezésében a reziliencia maga a kedvezôtlen környezeti hatások ellenére létrejövô pozitív adaptáció, kedvezó fejlôdési kimenetel. Masten (2001) késôbb már egy teljes jelenségcsoportként, hétköznapi csodaként írja le, amelyben szintén a pozitív végeredményre fókuszál. Mások szerint analitikailag megkülönböztetendô a reziliencia és a végeredmény. Szerintük a reziliencia ok-okozati összefüggésben áll a többé-kevésbé kívánatos eredményekkel, például olyan mechanizmusként értelmezik, amely moderálja a kapcsolatot a rizikótényezók és a végeredményváltozók között (Kaplan, 1999). Azonban gyakran olyan pontatlan a definíció megfogalmazása, hogy könnyen félreérthetô, hogy melyik jelentés alkalmazható.

Ma már egyetértenek a kutatók abban, hogy a reziliencia összetett, multidimenzionális jelenség, azonban egységesen elfogadott definícióról nem beszélhetünk. A szakirodalomban jelentôs különbségek fedezhetôek fel a fogalomba bevont összetevôket, a kritériumokat és standardokat illetôen (Prince-Embury, 2014). A kutatók egy része a két alapkritériumra: a rizikóra és a kedvezô fejlődési kimenetelre (Masten és Coatsworth, 1998) kiterjedô alapfogalmat határoznak meg, mint Garmezy, Masten és Tellegen (1984) fentebb leírt korai definíciója. Késóbb Masten és Reed (2002) is a reziliencia két alapelemét emeli ki: az egyén jó boldogulását az életben és azt, hogy jelenleg vagy korábban nagymértékú rizikónak volt kitéve.

Mivel a rezilienciakutatások megindulásával egy idôben megindult azoknak a tényezóknek a feltárása is, amelyek az adaptív viselkedés létrejöttéhez hozzájárulnak, így a kutatók egy másik része által alkotott definíciókban az alapkritériumokon túl megjelennek a reziliencia további komponensei, a protektív tényezôk és a jelenség kialakulására ható egyéb tényezók. Connor és Davidson (2003) például a reziliencia mint személyiségbeli jellemzô multidimenzionalitását hangsúlyozzák, és a kontextus, az idő, a kor, a nem, a kulturális identitás hatását is a definíció összetevôi közé emelik. 
Kim-Cohen és Gold (2009) szerint pedig a reziliencia egy komplex multidimenzionális interakció és a rizikófaktorok, a biológiai funkciók, a környezeti és családi támogatás, valamint a protektív faktorok szerepére hívják fel a figyelmet, amelyek kombinációja egyedi módon jelentkezik minden gyermeknél.

\section{A reziliencia kutatásának hullámai}

A reziliencia fogalmának alakulását, a jelenség kutatásának fázisai is befolyásolták. Masten és Wright (2010) a kutatások négy hullámát különítette el. Megállapításuk szerint az elsố hullám kutatásai a jelenség leírására koncentráltak. A definíció és az értékelési lehetôségek kialakítása során azokat a különbségeket igyekeztek azonosítani, amelyek megkülönböztetik az akadályokkal sikeresen és sikertelenül megküzdóket. A kutatók konzisztenciát fedeztek fel az egyén rezilienciát jósló tulajdonságai, kapcsolatai és erôforrásai között, amelynek hatására a potenciális védôfaktorok körének feltárása nagy szerepet játszott a késôbbi kutatásokban.

A második hullám során a faktorok jellemzóinek leírása helyett már a folyamatra és a „hogyan” kérdésére fókuszáltak, valamint azonosítani, értelmezni kezdték azt a speciális folyamatot és annak összetevőit, amely hatására a reziliencia megnyilvánul. Az ekkoriban elkészített alapmodellek a kompenzációt és mérséklést állították középpontba, és csökkentették a magyarázó összetevôknek tulajdonított hatást.

A kutatások harmadik hulláma során megkezdték a reziliencia fejlesztésére irányuló intervenciós programok kipróbálását. Majd a jelenlegi negyedik hullám hatására a reziliencia értelmezési köre az előbbieken túl is kiszélesedett. Ungar (2008) például az ismert problémák fényében egy újabb aspektusra, a reziliencia ökológiai szemléletû értelmezésére helyezi a hangsúlyt. Ez az értelmezés nem szúkíti be a lehetôségeket. A szerzó szerint a reziliencia lehet kimenetel és folyamat is egyszerre, személyen belüli tényezók által meghatározott és a környezettel való szoros kapcsolatban kiváltódó egyaránt. A meghatározás szerint a reziliencia egyszerre jelentheti az egyén kapacitását a sikerhez való út megtalálásában és az egyén környezetében (családjában, közösségi és kulturális közegében) fellelhetô feltételeket.

\section{A reziliencia kapcsolata más fogalmakkal}

A reziliencia jelentéstartalmának meghatározásakor, valamint a kutatási eredmények egységesítésekor további nehézséget jelent, hogy a nemzetközi szakirodalomban több, a rezilienciával funkcionálisan megegyezô terminus él egymás mellett, mint például a sebezhetetlenség (invulnerability) vagy stresszrezisztencia (stress-resistance) (Garmezy, 1985). Egyfajta megfogalmazásban például sebezhetetlennek nevezhetóek azok a gyermekek, akik kimagasló tanulmányi átlaggal rendelkeznek, annak ellenére, hogy alacsony szocioökonómiai státuszú családból származnak (Alva, 1991).

Több kutató hasonló megállapításra jutott, majd kutatásaik során egy terminust kiválasztva összevetettek hasonló fogalmakat. Például Lösel, Bliesener és Koferl (1989) a sebezhetetlenséget középpontba állítva megállapította, hogy számos fogalom hasonló 
jelentéstartalommal bír (resilience, hardiness, adaptation, adjustment, mastery, plasticity, person-environment fit, social buffering). Így az ezek köré a fogalmak köré épülố kutatási eredmények még tovább bóvíthetik a rezilienciáról alkotott tudáshalmazt.

\section{A REZILIENCIA VIZSGÁLATÁNAK LEHETŐSÉGEI}

A jelenség vizsgálatának nehézségei és a kutatási terület összetettsége nemcsak a rezilienciadefiníciók variabilitásában gyökerezik. A terület komplexitása következtében számos, a jelenség összetevôihez füzôdô szempontot kell figyelembe venni a kutatások megbízhatóvá tétele során.

Az értékelési lehetôségeket alapvetően meghatározza az a két alapkritérium, amely minden definícióban szerepel: a rizikó és a kedvezố fejlódési kimenetel. Ugyanis csak kimutatható rizikó esetében beszélhetünk rezilienciáról, valamint azt is meg kell határozni, hogy mit tekintünk megfelelő alkalmazkodásnak, sikeres végkimenetelnek, hiszen ennek hiányában nem értékelhetô a jelenség. Ezeknek az alapkritériumoknak a meghatározásában és értékelésében is nagy változatosság figyelhetô meg. Különbségek fedezhetôek fel annak megállapításában, hogy az egyént ért hátrányok természete váltja-e ki a rezilienciát, és hogy pontosan mekkora az a pozitív eredmény, amely már adaptív reakciónak számít (Prince-Embury, 2014).

\section{A rizikótényezók értelmezése és értékelése}

Általánosságban a rizikó megnöveli a negatív végkimenetel eloofordulásának valószínûségét (WHO, 2002). Számos, a reziliencia témaköréhez nem feltétlenül kapcsolódó kutatás foglalkozik a rizikó múködésének és hatásának feltárásával, például az egészség témakörével összefüggésben. Így az értékelésével és értelmezésével kapcsolatban is számos információra tehetünk szert a kapcsolódó kutatások feltárásával. Jelen fejezet a reziliencia kontextusához szorosan kapcsolódó, a fejlódéslélektani, valamint egészségpszichológiai szakirodalomban felmerülô legfontosabb értelmezésbeli és értékelésbeli kulcspontokról szól.

A kifejezetten rezilienciafókuszú kutatások során is sokféle akadály és hátráltató tényezô hatását vizsgálták már (pl. organikus zavarok, rossz szülôi bánásmód és szociális hátrányok, rossz szociokulturális körülmények, szegénység stb.). A kutatási területen leginkább a rizikótényezô terminust alkalmazzák a jövôbeni negatív kimenetelt bejósló tényezók megnevezésére. A kifejezésen az egy adott csoportra és az abba tartozó egyénekre és helyzetükre jellemzô mérhetô tulajdonságot értenek (pl. stresszes életesemények) (Masten és Reed, 2002). A rizikótényezók értékelésével kapcsolatban több probléma is felmerülhet, valamint a pontos hatások megállapítását is számos körülmény befolyásolja, amelyek az értékeléskor alkalmazható módszerek kiválasztását, az eredmények értelmezését és késôbbi vonatkoztatási lehetôségeit is meghatározzák.

Egyrészt nehézséget okozhat a rizikótényezóknek az a tulajdonsága, hogy ritkán fordulnak elő önmagukban, legtöbbször egymást felerôsítve, összesített hatást gyakorolnak (Masten, Herbers, Cutuli és Lafavor, 2008). A kezdeti kutatások gyakran egy 
fố hátráltató tényezốre vagy annak indikátorára fókuszáltak, azonban az eredményekbôl kiderült, hogy a hátrányokkal küzdôk helyzete bonyolultabb képet mutat. Azok a gyermekek, akiknek csak egy-két tényezôvel szemben kell helytállniuk, másképp viselkednek, mint a halmozott tényezók okozta hatásokkal megküzdôk (Waxman, Gray és Padrón, 2003). Így a kutatók a több tényezô között fennálló kapcsolati háló következtében, a rizikótényezôk összetett hatására, a kumulatív rizikóra kezdték fektetni a hangsúlyt (Masten és Powell, 2003). A kumulatív rizikón így az a teljes hatás értendô, amely több rizikótényezô kombinálódása vagy egyidejû halmozódása során jön létre (Masten és Reed, 2002).

A magas együttes eloofordulás problematikussá teszi a specifikus hatások elkülönítését (Coie, Watt, West, Hawkins, Asarnow, Markman, Ramey, Shure és Long, 1993). Waxman, Gray és Padrón (2003) szerint a halmozódást és a mélységet mérhetôvé kell tenni ahhoz, hogy hasznos információkra lehessen szert tenni, és következtetni lehessen a személyek rezilienciájának fokára. Azt is szükséges eldönteni, hogy a kumulatív rizikónak milyen hatásmechanizmust tulajdonítunk. Appleyard, Egeland, van Dulmen és Srouge (2005) a kumulatív rizikó értékelésének és hatásának két modelljét különítették el. A „küszöb modell” azt feltételezi, hogy a rizikótényezók egy bizonyos számának elérése drámaian megnöveli a negatív kimenetel létrejöttét. Az „additív modell” szerint azonban a rizikótényezôk számának növekedésével összhangban folyamatosan nô a negatív kimenetel létrejöttének valószínúsége. Appleyard és munkatársai (2005) a két modell közül a másodikat részesítik elônyben, mivel ez az elképzelés azt a fontos álláspontot támasztja alá, hogy nem létezik a rizikónak olyan magas mértéke, amelyet elérve a gyermekek reménytelenné és az intervencióra alkalmatlanná válnának.

A kumulatív hatások mellett nagy jelentôsége van a rizikótényezók egyénhez, illetve végkimenetelhez való kapcsolódásának, vagyis a közeliségnek és a távoliságnak a mértéke (Luthar, Cicchetti és Becker, 2000). Az egyén által közvetlenül megélt események a proximális tényezôk. Ezek hatásukban különböznek a disztális vagy globális tényezôktôl, amelyek inkább az egyén környezetére, a kontextusra jellemzôk, de proximális folyamatok szabályozzák múködésüket.

További problémát jelenthet a rizikós életesemények megélésének szubjektivitása, az ok-okozati kapcsolatok nem egyértelmúsíthetô iránya és a hatások idôbeli változása. A rizikóval kapcsolatos kutatások szerint nem egyforma hatások érik az egyes rizikónak kitett egyéneket, így szubjektív lehet, hogy egy adott rizikótényezô milyen hatással van a negatív körülményekkel való megküzdésre (Rutter, 2007). Az ok-okozati kapcsolatok nem egyértelmúsíthetố iránya abban nyilvánul meg leginkább, hogy a vizsgálatokban részt vevôk személyiségétôl és viselkedésétôl nemcsak a reziliens reakció létrejötte függ, hanem fordítva, maga a rizikó mértéke is (Masten és Reed, 2002). Az életkor változása és a rizikótényezók fejlődési folyamattal kapcsolatos összhangja akadályt jelenthet a pontos hatások feltárásában és az esetleges intervenció során, ugyanis az életkor elôrehaladtával változást mutattak ki a hatást gyakorló tényezôk körében és hatásuk erôsségében (Masten és mtsai, 2008). Egyes tényezôk a fejlôdés egy meghatározott, kritikus pontján specifikus hatást gyakorolhatnak, míg más életszakaszokban kevéssé erôs a hatásuk. Például a gyermekbántalmazásnak nagyobb hatása van a fiatalabb életkorban, mint a nagyobb gyermekek esetében (Glaser, 2000). Természetesen az, hogy 
melyik fejlődési szakaszban merül fel a rizikótényezô, összhangban van az elôzóekben említett szubjektivitással és a probléma mibenlétével is (Frick, 2004). Ezek a körülmények mind meghatározhatják, hogy a kutatási eredmények miként értelmezhetôek és miképpen általánosíthatóak szélesebb körben.

\section{A rizikótényezók vizsgálatának módszerei}

A rizikótényezôk értékelésének problémáira a minta kiválasztásával, a vizsgálni kívánt tényezôk körének pontos meghatározásával, a vizsgálatukra alkalmazott indikátorok szakszerú behatárolásával és a megfelelô módszerek használatával reagálhatunk.

A kutatások során a mintába kerülés feltételeinek még a vizsgálat elôtti meghatározásával, a kiválasztás és a vizsgálatba való bevonás nehézségeivel számolni kell. Egyes rizikótényezôk esetében az információgyújtés nehezített lehet valamint, a minta kiválasztásakor azt is érdemes meghatározni, hogy a mintába kerülő tanulók mindegyike közel hasonló szintú rizikónak van-e kitéve vagy sem (Luthar, Cicchetti és Becker, 2000). A rizikó megítélésére (attól függôen, hogy mely tényezôkrôl, milyen módszerrel és kitôl kerülnek begyújtésre az adatok) szubjektív vagy objektív értékek is alkalmazhatóak, amelyek kiválasztása a kutatási eredmények megbízhatóságát befolyásolhatja (Masten és Reed, 2002).

Luthar és Cushing (1999) a rizikótényezók empirikus vizsgálatának alapvetôen három megközelítését különítették el, más kutatók munkáiban ezekhez kapcsolódó módszertani információk is fellelhetôek. Az elsô megközelítés feleletválasztós kérdôiveket és interjúkat alkalmaz a rizikótényezóknek való kitettség mértékének megállapítása érdekében. A kérdôívek leggyakrabban a negatív vagy stresszes életesemények számbavételére fókuszálnak (pl. Garmezy, Masten és Tellegen, 1984), de bizonyos esetekben olyan további rizikókörülményekrôl is adatokat gyújtenek, mint a családi kapcsolatok és körülmények (Baldwin, Baldwin, Kasser, Zax, Sameroff és Seifer, 1993) vagy egyéb anamnesztikus jellegú adatok. A rizikófaktorok hatását a begyújtött információk és a pozitív vagy negatív kimenetel közötti korreláció vizsgálatán keresztül értelmezik (Luthar és Cushing, 1999).

Egy másik megközelítés a rizikójelenségek összetettségére helyezi a hangsúlyt és speciális rizikóindexek alkalmazásával értékeli a veszélyeztetettség szintjét. Olyan háttéradatokat és szociodemográfiai információkat hasznosít, mint az alacsony családi jövedelem, szülook iskolázottsága, kisebbségi csoportba tartozás stb. A szerzók szerint ez a megközelítés kifejezetten a kumulatív rizikó (pl. szegénység) értékelését kívánja megvalósítani (Luthar és Cushing, 1999).

Ehhez kapcsolható Masten és Reed (2002) módszertani útmutatása, akik a kumulatív rizikó értékelésének két fő formáját különítették el, és nemcsak a rizikóindexeket, hanem az elsố megközelítésben szereplő stresszes életesemények pontozását is értékelésre alkalmas formaként jelölik meg. A kumulatív rizikó mérôszámát gyakran a gyermek életében megmutatkozó rizikófaktorok számának összesítéséból alakítják ki, ami stresszes vagy negatív életesemények számából is következhet. Azonban a szimpla összesítés nem árulkodik arról, hogy milyen mélységú a rizikótényezô hatása, ezért a súlyossági fok külön értékelhetô is lehet. 
A Luthar és Cushing (1999) által osztályozott harmadik megközelítés ezektôl elkülöníthetô, mivel egy, az egész életre kiható, magas rizikót feltételezô specifikus tényezốt (pl. gyermekbántalmazás, háborúnak való kitettség) vesz figyelembe a hatások vizsgálatakor, amely gyakran a minta kiválasztásának is az alapját képezi. A statisztikai elemzéskor ebben az esetben is a kedvezô kimenetellel való szignifikáns korrelációt veszik alapul.

\section{A kedvezô fejlōdési kimenetel értelmezése és értékelése}

A kedvezó fejlôdési kimenetel meghatározása is a reziliencia jelenségének alapkritériuma. A kutatásokban számtalan kritériumot alkalmaznak az értékelés során. Például a pozitív viselkedés (szociális és tanulmányi kontextusban) és más társadalmilag kívánatos, az életkornak megfelelô viselkedés megléte (pl. boldogság, elégedettség az élettel), vagy épp ellenkezóleg, a nemkívánatos viselkedés (pl. mentális betegségek, stressz, bûnözô életmód, kockázatkeresô viselkedés) is kritériumként jelenik meg (Masten és Reed, 2002).

Azonban a kedvezó kimenetel pontos értelmezése és értékelésének lehetôsége a rizikóéhoz hasonlóan változatos. Megítélése elsôsorban a létrejövô kedvezô fejlôdési kimenetel sokszínúsége, valamint a kontextusfüggôség és a kulturális érzékenység következtében nehézkes (Liebenberg és Ungar, 2009). Életkoronként, társadalmanként, veszélyeztetettségi szintenként és történelmi koronként eltérô, hogy mikor beszélhetünk kedvezó kimenetelrôl (Masten és Powell, 2003). A kultúra, a beszélt nyelv, a gazdasági, az etnikai, nemi és megélt életesemények szerinti különbségek is (Liebenberg és Ungar, 2009) jelentôsen meghatározhatják, hogy mi tekinthetô sikernek.

A problémák kezelése érdekében sok kutató az életkorhoz köthetô, a sikerek típusát rögzítô standardok alapján határozza meg a kedvezô kimenetelt (Masten és Reed, 2002), melyek kultúránként eltérô elemeket is tartalmazhatnak, de a tágabban értelmezettek egyezhetnek is, hiszen bizonyos képességek fejlôdése (pl. csecsemôk esetében) kultúrától független. Ezek a standardok vagy fejlôdési szintek a különbözô életszakaszokban és szituációkban elvárható gyermeki viselkedés leírását tartalmazzák, egy adott kultúra vagy társadalom elvárásainak és a történelmi kontextusnak megfelelő́en (Masten és Coatsworth, 1998). Masten, Coatsworth, Neemann, Gest, Tellegen és Garmezy (1995) például az adaptív viselkedés definiálására a kompetencia terminust alkalmazzák, és meghatározzák a tartalmát, vagyis azt, hogy egy adott életkorban milyen területeken érthetố el pozitív teljesítmény. Az iskoláskorú gyermekek esetében például megkülönböztetik az iskolai teljesítmény területén mutatott sikert, a kortársak és szociális kapcsolatok terén elérhetố sikert, valamint az otthon, az iskola és a közösségben meghatározott szabályok követése terén mutatott viselkedés megfelelőségét.

Más kutatók fố rezilienciatípusokat különítenek el a végkimenetel és a megélt körülmények szempontjából, így kezelve a reziliens reakció sokszínúségét. Bradley, Whiteside, Mundfrom, Casey, Kelleher és Pope (1994) a kognitív, a viselkedéses, a növekedési státuszbeli és az egészségi állapotban megmutatkozó rezilienciát különítette el egymástól. Luthar, Cicchetti és Becker (2000) pedig megkülönbözteti a tanulmányi rezilienciát az érzelmi, valamint a viselkedéses rezilienciától. Masten, Best 
és Garmezy (1990) a megélt körülmények alapján szintén három altípust különít el. Az egyik típusba tartoznak azok az egyének, akik a magas rizikójú háttér ellenére, a vártnál kedvezóbben teljesítenek. A második esetében a stresszel való megküzdés áll a középpontban, a stresszes tapasztalatok ellenére létrejövô kompetenciát jelöli. A harmadik már a traumából való felépülést foglalja magában (pl. háborúk vagy természeti katasztrófák okozta krízis).

A kulturális érzékenység okozta nehézségek kezelése érdekében a vizsgálni kívánt közösség specifikumait figyelembe vevô, a helyi sajátosságokra, tradíciókra és értékekre érzékeny értékelési koncepciók kialakítását javasolják a kutatók (Liebenberg és Ungar, 2009). Mindezek mellett a vizsgálatba bevont kimeneti változók kiválasztásakor a kutatók és a kutatásban részt vevôk közötti távolságot is figyelembe kell venni, mivel mélyen gyökerezó különbségek vannak a fiatalok és a felnôttek perspektívái között (Karlsson, 2001). A vizsgálatot végzô és annak eredményét meghatározók (pl. kutatók, tanárok) nehezen ítélhetik meg, hogy a kutatásba bevonni kívántak miként interpretálják a világot és a sikerességet.

Egy, a reziliencia kutatásának szakirodalmában folytatott vita arra fókuszál, hogy ezeknek a standardoknak csak a belsô (pl. érzelmi jóllét) vagy egyben a külsô (pl. iskolai jó teljesítmény) sikeres adaptációt is tartalmaznia kell-e (Masten és Reed, 2002). Abban mindkét tábor egyetért, hogy a külsô sikerekre vonatkozó standardok meghatározó elemei a rezilienciának. A probléma megléte a fogalom definiálására vonatkozó egyezôtlenségekkel, a külsố tényezôk definícióba való beemelésével és az ökológiai szemléletú értelmezés hatásával kapcsolható össze, amelyrôl magyarul bôvebben olvashatunk Szokolszky és V. Komlósi (2015) tanulmányában.

Egy másik vita annak megállapításához kapcsolódik, hogy a rezilienseknek milyen mértékben kell jól funkcionálnia ahhoz, hogy az normál tartományúnak legyen tekinthetô (Masten és Reed, 2002), vagy mekkora az a pozitív eredmény, amely már adaptív reakciónak számít (Prince-Embury, 2014). A probléma kezelésére egyes kutatók a jó körülhatárolhatóság okán a hátrányokkal kiemelkedôen jól megküzdôk teljesítményét vizsgálják. Azonban a kutatók többsége a normál tartományban teljesítôket is bevonja a kutatásba, amit azzal magyaráznak, hogy a céljuk az, hogy megértsék az egyénnek azt a tulajdonságát, amellyel fenntartja vagy visszanyeri normál állapotát (Masten és Reed, 2002), és erre az átlagosan teljesítőek megfigyelése is alkalmas.

\section{A kedvezô fejlôdési kimenetel vizsgálatának módszerei}

A reziliencia jelenségének operacionalizálása során alkalmazott megközelítés a kedvezô fejlôdési kimenetel vizsgálatának lehetôségeit is meghatározza. A felhasználható módszerek széles skálán mozognak, s mint fentebb a rizikó esetében, vele valamelyest analóg módon itt is három megközelítést különítettek el (Luthar és Cushing, 1999).

Az elsố megközelítés a tapasztalható kompetens teljesítményre vagy megfelelô viselkedésre vonatkozó adatok összegyújtését foglalja magában. A reziliencia definíciójától, vagy a sikeres alkalmazkodás vizsgált típusától függően ez sokféle eszközt és módszert takarhat. Masten és Reed (2002) szerint a gyermekek és fiatalok esetében tipikusan a tanulmányi sikerességet, a magatartást, a kortársak általi elfogadást és baráti kapcsola- 
tokat, a mentális egészséget és az életkornak megfeleló, iskolán kívüli tevékenységekben való részvételt értékelik. A legtöbb kutatásba nemcsak egy, hanem egyszerre több ilyen indikátort is bevonnak. A tanulmányi területen kimutatható sikeresség esetében például tesztekkel értékelik a tanulók teljesítményét, vagy az iskolai sikeresség egyéb mutatóit (pl. érdemjegyek) veszik alapul (pl. Garmezy, Masten és Tellegen, 1984). A szociális és emocionális alkalmazkodás esetében pedig az értékelhetô viselkedést veszik figyelembe, a tanulók, tanárok szülők vagy kortársak által kitöltött feleletválasztós kérdöíveket alkalmazva.

Egy másik megközelítés esetében az alkalmazkodás eltérô aspektusainak bevonásával értékelik a kompetenciát és összesített mutatókat képeznek a különbözô területeken elért teljesítményeket összevonva. Például a tanulmányi területen mutatott teljesítményt és a szociális érvényesülést is figyelembe veszik, mint a Project Competence során tették a reziliens viselkedés értékelése során (Masten és Powell, 2003).

Az ezektôl elkülönülô megközelítés a fontosabb tünetek meglétét vagy hiányát veszi számba, és abból következtet a pozitív teljesítmény megvalósulására. Ez általában azokhoz az esetekhez kapcsolódik, amikor egy speciális rizikótényezônek (pl. háborúnak való kitettség vagy egyéb pszichopatológiai rendellenességek) kitett csoport sikeres alkalmazkodásának formáját vizsgálják. Az adatgyújtés általában kvalitatív módszerekkel történik, strukturált, vagy félig strukturált interjúkat használnak (Luthar és Cushing, 1999).

\section{A protektív tényezók, erôsségek és erôforrások értelmezése és értékelése}

A rizikót és a kedvezô fejlôdési kimenetelt a reziliencia két alapkritériumának tekintik a kutatók, de mellettük egy harmadik, legalább olyan fontos, a kettô közötti kapcsolat létrejöttéhez feltétlen szükséges összetevő van. A kutatók gyakran ezeknek a tényezôknek a vizsgálatát értik a reziliencia kutatása alatt, így e tényezôk vizsgálata és hatásuk értelmezése elengedhetetlen a jelenség megértéséhez, jelentéstartalmának meghatározásához. A rezilienciakutatások során mindig felmerül a kérdés, hogy mi az, ami a különbségeket okozza. Az egyénnek vagy a környezetének mely tulajdonsága magyarázhatja, hogy néhányan jobban, míg mások kevésbé képesek megküzdeni az akadályokkal? A pozitív tulajdonságokra vonatkozó erôsségek, erôforrások és protektív tényezôk koncepciója, és azok tanulmányozása alkalmas lehet a jelenség magyarázatára. De ahogyan a két alapkritériumét, úgy a kedvezô kimenetel létrejöttéhez szükséges tényezôk értelmezését és értékelését is számos tényezô befolyásolja, a definiálási nehézségektôl a módszertanra hatással levô tényezókig.

Masten és Reed 2002-es tanulmányukban pontosan körülhatárolják a koncepcióhoz tartozó fogalmak közötti különbségeket. Az erôsségek (assets) fogalma alatt olyan mérhetố tulajdonságokat értenek, amelyek a rizikófaktorok ellentétei. A jelenlétük egy vagy több specifikált területen bejósolja a kedvezóbb kimenetel létrejöttét, a rizikó meglétére való tekintet nélkül. Az erőforrás (resource) általános fogalom, mely az adaptív folyamatokhoz felhasználható emberi, szociális és anyagi javakat jelöli, gyakran az erôsségek szinonimájaként használják. A protektív faktorok (protective factors) az egyén vagy a környezet azon tulajdonságai, amelyek a kedvezó kimenetel létrejöttét jósolják 
be a rizikós körülmények között is, vagyis olyanok, mint az erôsségek, a különbség a rizikó jelenlétében van. Ebben az értelmezésükben a protektív tényezók azok, amelyek csak a rizikó előfordulása esetén érvényesítik hatásukat, annak hiányában nem lépnek múködésbe. Egyes kutatók ezt a fogalmat tehát kifejezetten azoknak a prediktoroknak a körére alkalmazzák, amelyek hatásmértéke a rizikóéval van összhangban. A protektív faktorok a rizikó szintjének megfelelốn múködnek, a rizikó emelkedésével növekszik hatásuk, míg azok csökkenésekor kevésbé hatnak.

Más kutatók is a rizikó inverzének tekintik a protektív tényezóket. Smith és Carlson (1997) szerint módosíthatják, enyhíthetik a rizikótényezók egyénre gyakorolt negatív hatásait, így hozzájárulva a kedvezô végeredmény létrejöttéhez. Durlak (1998) szerint míg a rizikó növeli, addig ezek a tényezôk csökkentik a negatív végkimenetel elôfordulásának valószínúségét, a rizikótényezôk hatásának bufferelése által.

A protektív tényezók eképp való értelmezésébôl egyértelmúen adódik, hogy számos hasonló probléma merül fel a két terület értékelése során. Így a korábbi, rizikótényezôk értelmezésével és vizsgálatával foglalkozó fejezetben említett megállapítások egy része a protektív tényezôk esetében is érvényes. Amennyiben a protektív tényezók sokszorozódnak, kumulatív hatás jöhet létre, vagyis a protektív faktorok növekvô száma megmutatkozik a siker valószínúségének növekedésében (Rutter, 1999).

Az életkorral és a fejlôdési szakasszal a rizikóhoz hasonlóan a protektív faktorok is kapcsolatban vannak. Itt is érvényes a megállapítás, hogy egyes tényezók megléte eltérô életszakaszokban eltérô hatásmértékú. A szubjektivitás és az egyén személyisége, valamint az ok-okozati kapcsolatok irányának tisztázatlansága itt is nehézségek elé állítja a területtel foglalkozó kutatókat és a lehetséges intervenciót szervezô szakembereket. Így a protektív tényezôk értékelése során is figyelembe kell venni ezeket a befolyásoló hatásokat.

\section{Protektív tényezôk vizsgálatának módszerei és a rezilienciamodellek}

A rezilienciakutatások során számos módszerrel próbálták meg azonosítani azokat a protektív tényezôket, amelyek segítik a hátrányok leküzdését és hozzájárulnak a kedvezô fejlődési kimenetel létrejöttéhez. A vizsgálat fókusza alapján két központi megközelítés alakult ki: a változókra fókuszáló megközelítés (pl. Garmezy, Masten és Tellegen, 1984; Luthar, 1991) és a személyre fókuszáló (pl. Werner és Smith, 1992; Masten, 2001).

Ezek a megközelítések nemcsak mint a protektív tényezôk vizsgálatának megközelítései terjedtek el a kutatási terület fejlôdése során, hanem mint magának a reziliencia kutatásának megközelítései vagy modelljei. Ugyanis a kutatók sokszor a protektív tényezôk feltárását értik a reziliencia vizsgálata alatt. Masten (2001) és késóbb Masten és Reed (2002) is részletesen és strukturáltan mutatják be a változókat középpontba állító és a személyeket középpontba állító rezilienciamodelleket, így jelentôségük következtében kitérünk ezekre a modellekre, de csak a szerzôk legfontosabb megállapításait emeljük ki.

A változókat középpontba állító megközelítés vagy modellek az egyéni tulajdonságok, a környezet és a tapasztalt életesemények közötti kapcsolatok magyarázatán keresztül kívánják megállapítani, hogyan jön létre a kedvezó fejlôdési kimenetel. 
A többváltozós statisztikai módszereket alkalmazó megközelítés statisztikai modellek tesztelésével vizsgálja a veszélyeztetettségi szint és az elért teljesítmény minôsége közötti kapcsolatot (Masten, 2001), így alkalmas a protektív faktorok körének feltárására és múködésük módjának behatárolására (Masten és Reed, 2002), valamint az elórejelzó tényezők és a kimenetel közötti kapcsolat mérésére (Masten, 2001).

Már a korai kutatásokban alkalmazták ezt a szemléletet. Elônye, hogy a kialakított modellek nemcsak a hipotetikus protektív faktorok hatásának vizsgálatára alkalmasak, hanem az intervenciós eljárások kialakításának is alapjául szolgálhatnak. Hátránya, hogy sok esetben a változók statisztikai értékelése áll a középpontban, így kevésbé veszi figyelembe a valós élet jellemzőit, valamint a szélsôséges helyzetek közötti átfogó különbségeket (Masten, 2001).

A kutatások során több ilyen modellt is teszteltek: az additív, az interaktív és az indirekt modelleket (Masten és Reed, 2002). Az additív modellekben három külön csoportba sorolják a vizsgálatba bevonni kívánt tényezóket. A tiszta rizikófaktorok és erôforrásfaktorok negatív, illetve pozitív hatása közvetlenül hat a kedvezó kimenetel létrejöttére. A rizikó feltûnése esetén a siker létrejöttének valószínúsége egyértelmúen csökken, amennyiben nincsenek jelen, úgy semmiféle hatást nem gyakorolnak rá. A tiszta erôsségek vagy erőforrások szintén hasonlóan hatnak, csak ellentétes irányban. Jelenlétük esetében a siker létrejöttének valószínúsége nô, azonban nem csökkenti azt, amennyiben nincsenek jelen. Ezek mellett megkülönböztetendô a tényezôk egy harmadik csoportja, amely a rizikót és az erőforrást egyesíti. Ezek olyan bipoláris tényezôk (risk-asset attributes), amelyek pozitív túlsúlya esetén a siker valószínûsége nô, míg negatív súlyuk esetén csökken. Például a gyermekek környezetére jellemzô tényezôk közül a szocioökonómiai státusz magas szintje erőforrásként hat, míg alacsony szintje rizikóként múködik.

A személyre fókuszáló megközelítés vagy modellek az egyének közötti különbségeket állítják középpontba (Masten, 2001). A reziliensek és nem reziliensek csoportjának azonosítása és összehasonlítása alapján kívánja kideríteni, hogy miképp jön létre az adaptív reakció (Masten és Reed, 2002). Az eltérô kimeneti teljesítményt nyújtó csoportok összehasonlítása során az azonos rizikófaktorba tartozókat vizsgálják (Masten, 2001). Alkalmas a szokásos és a nem szokványos mintázatok mélyebb vizsgálatára, valamint a sokrétú folyamatok feltárása. Ez a megközelítés kevésbé érzékeny, mint a változókra összpontosító, azonban az eredmények általánosíthatósága nehézséget okozhat, mivel elhomályosíthatja a speciális kapcsolódásokat, a nagyobb összefüggések feltérképezését, amelyek elősegíthetnék a folyamatok megértéséhez szükséges központi tényezók megtalálását (Masten, 2001).

Masten és Reed (2002) a személyekre fókuszáló modelleknek három fajtáját különítik el. Az egyik modell egyszerú esettanulmányokat használ fel az egyéni életutak bemutatására és ezáltal a reziliencia létrejöttének magyarázatára. Ezek az esettanulmányok nem igazi rezilienciamodellek, inkább heurisztikus célokat szolgálnak, de bizonyítékai a jelenség természetes létrejöttének és múködésének. A személyeket középpontba állító rezilienciamodellek másik fajtája a nagyon magas rizikónak kitett egyének azonosításán és életútjuk elemzésén alapszik. Ennek a klasszikus megközelítésnek jó példája az elsố rezilienciakutatások egyike, a Hawaiin végzett kauai longitudinális ku- 
tatás (Werner és Smith, 1992), amely során több mint hatszáz személy fejlôdését követték nyomon a születésüktôl negyvenéves korukig. A kutatás során azokat sorolták a reziliens csoportba, akik legalább négy rizikótényezônek voltak kitéve kétéves korukig, majd pozitív eredményeket mutattak a kompetencia, a magabiztosság és a gondoskodó felnôtté válás területein. Ez a megközelítés gyakran szolgáltat bizonyítékokat arra vonatkozóan, hogy milyen szembetûnốek a különbségek a jelenség létrejöttéhez szükséges erôsségek és emberi, valamint társadalmi tôke körében. Ennek a megközelítésnek a korlátai vezettek a harmadik, a teljes diagnosztikus modellek létrejöttéhez. Ugyanis a nézettel kapcsolatban megfogalmazott kritikák egyike szerint az efféle elemzésekbool hiányoznak az alacsony rizikónak kitett alcsoportok. A teljes diagnosztikus megközelítés kutatásaiban szerepelnek az átlagos populáció tagjai is a célból, hogy a rezilienseket össze lehessen hasonlítani az alacsony rizikónak kitett egyénekkel és a magas rizikónak kitett, de maladaptív viselkedést mutató társakkal egyaránt.

\section{ÖSSZEGZÉS}

A rezilienciára fókuszáló kutatások kivitelezését számos ellentmondásos körülmény és tényezô nehezíti, amelyek figyelembevétele feltétlenül szükséges az érvényesíthetô eredmények feltárásához.

A reziliencia jelenségének összetettsége már a kutatások elsô fázisát nagyban befolyásolja, mivel a kutatási céloknak megfelelő definíció kiválasztása hatással van az alkalmazható értékelési módszerek kiválasztására és a kapott eredmények késôbbi értelmezhetôségére és általánosíthatóságára egyaránt. De a jelenség szinte minden vizsgálandó összetevôjéhez választható opciók sora kapcsolódik, amelyek egységesítése még várat magára. A témával foglalkozó kutatók is felhívják a figyelmet a konstruktum bonyolultságára és a számos buktatóra, amelyek hatással vannak a vizsgálatok reliabilitására és validitására. Ezért a szakirodalmi tanulmány célja a jelenség komplexitásának bemutatása és az értékelése során felmerülô kérdéseknek a felvetése volt, annak érdekében, hogy segítse a hazai rezilienciafókuszú kutatások megindulását és megalapozottá válását. A jelenség értelmezésével és értékelésével kapcsolatos problémafelvetések mellett a kutatási irányok meghatározását és a kutatások kivitelezését további, a problémakörrel foglalkozó kutatási eredmények bemutatása és egységesítése segítheti.

\section{IRODALOM}

Alva, S. A. (1991). Academic invulnerability among Mexican-American students: The importance of protective resources and appraisals. Hispanic Journal of Behavioral Sciences, 13(1), $18-34$.

Appleyard, K., Egeland, B., van Dulmen, M., \& Srouge, L. (2005). When more is not better: The role of cumulative risk in child behavior outcomes. Journal of Child Psychology and Psychiatry, 46(3), 235-245.

Baldwin, A. L., Baldwin, C. P., Kasser, T., Zax, M., Sameroff, A., \& Seifer, R. (1993). Contextual risk and resiliency during late adolescence. Development and Psychopathology, 5(4), 741-761. 
Békés, V. (2002). A rezilienciajelenség, avagy az ökologizálódó tudományok tanulságai egy ökologizált episztemológia számára. In Forrai Gábor \& Margitay Tihamér (szerk.), Tudomány és történet: Fehér Mártának tisztelói és tanítványai. Budapest: Typotex. Letöltve: 2015.11.12-én:

http://nyitottegyetem.phil-inst.hu/Bekes_fehermarta.pdf

Block, J. H. \& Block, J. (1980). The role of ego-control and ego-resiliency in the organization of behavior. In W. A. Collins (Ed.), Development of cognition, affect, and social relations. The Minnesota symposia on child psychology (pp. 39-101). Hillsdale: Lawrence Erlbaum.

Bradley, R. H., Whiteside, L., Mundfrom, D. J., Casey, P. H., Kelleher, K. J., \& Pope, K. (1994). Early Indications of Resilience and Their Relation to Experiences in the Home Environments of Low Birthweight, Premature Children Living in Poverty. Child Development, 65(2), 346-360.

Coie, J. D., Watt, N. F., West, S. G., Hawkins, J. D., Asarnow, J. R., Markman, H. J., Ramey, S. L., Shure, M. B., \& Long, B. (1993). The science of prevention: a conceptual framework and some directions for a national research program. American Psychologist, 48(10), 1013-1022.

Connor, K. M. \& Davidson, J. R. T. (2003). Development of a new resilience scale: The Connor-Davidson resilience scale (CD-RISC). Depression and Anxiety, 18(2), 76-82.

Durlak, J. A. (1998). Common risk and protective factors in successful prevention programs. American Journal of Orthopsychiatry, 68(4), 512-520.

Frick, P. (2004). Developmental pathways to conduct disorder: Implications for serving youth who show severe aggressive and antisocial behavior. Psychology in the Schools, 41(8), 823-834.

Garmezy, N. Z. (1985). Stress-resistant children: The search for protective factors. In J. E. Stevenson (Ed.), Recent research in developmental psychopathology (pp. 213-233). New York: Pergamon Press.

Garmezy, N., Masten, A. S., \& Tellegen, A. (1984). The study of stress and competence in children: A building block for developmental psychopathology. Child Development, 55(1), 97-111.

Glaser, D. (2000). Child abuse and neglect and the brain - A review. Journal of Child Psychology and Psychiatry, 41(1), 97-116.

Kaplan, H. B. (1999). Toward an Understanding of Resilience. A Critical Review of Definitions and Models. In M. D. Glantz \& J. L. Johnson (Eds), Resilience and development: positive life adaptations (pp. 17-83). New York: Kluwer Academic/Plenum Publishers.

Kaplan, H. B. (2005). Understanding the concept of resilience. In S. Goldstein \& R. B. Brooks (Eds), Handbook of resilience in children (pp. 223-237). New York: Kluwer Academic/Plenum Publishers.

Karlsson, J. (2001). Doing visual research with school learners in South Africa. Visual Sociology, 16(2), 23-37.

Kim-Cohen, J. \& Gold, A. L. (2009). Measured gene-environment interactions and mechanism promoting resilient development. Current Directions in Psychological Science, 18, 138-142.

Lerner, R. M. (2006). Resilienc as an attribute of the developmental system. In B. M. Lester, A. Masters \& B. McEwan (Eds), Resilience in children: Annals of the New York Academy of Science (pp. 40-51). New York: New York Academy of Science.

Liebenberg, L. \& Ungar, M. (Eds) (2009). Researching resilience. Toronto: University of Toronto Press.

Lösel, F., Bliesener, T. \& Koferl, P. (1989). On the concept of invulnerability: Evaluation and first results of the Blielefeld project. In M. Brambring, F. Losel \& H. Skowronek (Eds), Children at risk: Assessment, longitudinal research, and intervention (pp. 186-219). New York: Walter de Gruyter.

Luthar, S. S. (1991). Vulnerability and resilience: A study of high risk adolescents. Child Development, 62(3), 600-616. 
Luthar, S. S., Cicchetti, D. \& Becker, B. (2000). The Construct of Resilience: A Critical Evaluation and Guidelines for Future Work. Child Development, 71(3), 543-562.

Luthar, S. S. \& Cushing, G. (1999). Measurement issues in the empirical study of resilience: An overview. In M. D. Glantz \& J. L. Johnson (Eds), Resilience and development: positive life adaptations (pp. 129-160). New York: Kluwer Academic/Plenum Publishers.

Masten, A. S. (2001). Ordinary magic: Resilience processes in development. American Psychologist, 56(3), 227-238.

Masten, A. S., Best, K. \& Garmezy, N. (1990). Resilience and development: Contributions from the study of children who overcome adversity. Development and Psychopathology, 2, 425-444.

Masten, A. S. \& Coatsworth, J. D. (1998). The Development of Competence in Favorable and Unfavorable Environments: Lessons From Research on Successful Children. American Psychologist, 53(2), 205-220.

Masten, A. S., Coatsworth, J. D., Neemann, J. Gest, S. D. Tellegen, A., \& Garmezy, N. (1995). The structure and coherence of competence from childhood through adolescence. Child Development, 66(6), 1635-1659.

Masten, A. S., Herbers, J. E., Cutuli, J. J., \& Lafavor, T. L. (2008). Promoting Competence and Resilience in the School Context. Professional School Counseling, 12(2), 76-84.

Masten, A. S. \& Powell, J. L. (2003). Resilience framework for research, policy and practice. In S. S. Luthar (Ed.), Resilience and Vulnerability (pp. 1-25). New York: Cambrige University Press.

Masten, A. S. \& Reed, M. G. (2002). Resilience in development. In C. R. Snyder \& S. J. Lopez (Eds), The handbook of positive psychology (pp. 74-88). New York: Oxford University Press.

Masten, A. S., \& Wright, M. O. (2010). Resilience over the lifespan: Developmental perspectives on resistance, recovery and transformation. In J. W. Reich, A. J. Zautra \& J. S. Hall (Eds), Handbook of adult resilience (pp. 213-237). New York: Guilford.

Prince-Embury, S. (2014). Review of resilience conceptual and assessment issues. In S. PrinceEmbury \& D. H. Saklofske (Eds), Resilience interventions for youth in diverse populations (pp. 13-23). New York: Springer.

Ribiczey, N. (2008). A rizikótényezóktôl a protektív mechanizmusokig: A reziliencia fogalmának alakulása a pszichológiában. Alkalmazott Pszichológia, 10(1-2), 161-171.

Rutter, M. (1999). Resilience concepts and findings: Implications for family therapy. Journal of Family Therapy, 21(2), 119-144.

Rutter, M. (2007). Resilience, competence, and coping. Child Abuse and Neglect, 31(3), 205-209.

Smith, C. \& Carlson, B. E. (1997). Stress, coping, and resilience in children and youth. The Social Science Review, 71(2), 231-256.

Sroufe, L. A. (1997). Psychopathology as an outcome of development. Development and Psychopathology, 9(2), 251-268.

Sugland, B. W., Zaslow, M., \& Nord, Ch. W. (1993). Risk, Vulnerability, and Resilience among Youth: in Search of a Conceptual Framework. Washington: Child Trends Inc., 1-39.

Szokolszky, Á. \& V. Komlósi, A. (2015). A „reziliencia-gondolkodás” felemelkedése - Ökológiai és pszichológiai megközelítések. Alkalmazott Pszichológia, 15(1), 11-26.

Ungar, M. (2008). Resilience across cultures. British Journal of Social Work, 38(2), 218-235.

Waxman, H. C., Gray, J. P., \& Padrón, Y. N. (2003). Review of research on educational resilience. Berkeley: University of California.

Werner, E. E. \& Smith, R. S. (1992). Overcoming the odds: High risk children from birth to adulthood. Ithaca: Cornell University Press.

World Health Organization (2002). The World Health Report 2002: Reducing risk, promoting healthy life. Geneva: World Health Organization. 


\title{
POSSIBILITIES OF INTERPRETATION OF RESILIENCE: CHALLENGES AND DIFFICULTIES
}

\author{
SZABÓ, DÓRA FANNI
}

The term resilience is becoming common. It appears increasingly and, as a system terminology, it is spreading fast between disciplines, making new research areas and new purposes. In social sciences, the term is used for both children and adults, who strive successfully in hazardous environment and despite difficulties. The investigation of the two fundamental judgements of the phenomenon, the risk and the positive developmental outcome, and the identification of its causes, became an intensively investigated area. It is inevitable to recognize the results of international research, their point of view, implement their methods and execute Hungarian investigations. However, the number of Hungarian studies in this topic is very limited (Békés, 2002; Ribiczey, 2008; Szokoszky E于 V. Komlósi, 2015).

Due to the complexity of the phenomenon and it's unclear operationalization, we need to take into account several factors in order to establish reliable investigations. The aim of this paper is to review these mentioned factors, so as to contribute to the planning and implementing research in Hungary. The definition of resilience defines the structure and the result of the investigation, thus the paper begins from the complexity of the term. Following that, the paper examines the circumstances which play a role in the interpretation and assessment of the phenomenon's two fundamental judgements, as well as summarises the assessment methods. Finally, it introduces the main terms of assets, resources and protective factors, that are inevitably required for the presence of positive developmental outcome. The paper also presents the variable- and person-focused models of resilience.

Key words: resilience, assessment, risk factors, protective factors 